\title{
Regulation without Representation? Independent Regulatory Authorities and Representative Claim- Making in the Netherlands, 1997-Now
}

\author{
Adriejan van Veen
}

\section{Introduction}

Independent regulatory authorities (IRAs) such as the Us Federal Trade Commission (FTC), the British Office of Communications (Ofcom), and the Dutch Autoriteit Financiële Markten 'Financial Markets Authority' (AFM) wield considerable public power in today's capitalist democracies. They regulate the behaviour of businesses and professions in liberalised marketplaces such as telecommunications, energy, public transport, financial markets, and healthcare. IRAs set prices and standards, regulate market and infrastructure access, and provide consumer information. They enforce compliance through banning, fining, or "naming and shaming" transgressors. IRAs also advise lawmakers on new regulatory frameworks, participate in transnational regulatory networks, and speak out on sensitive political matters. ${ }^{1}$ And yet, the decisions of these powerful public bodies are not fully controlled ex ante by either affected stakeholders or by democratic institutions such as government and parliaments. Even though their competences are demarcated by law, IRAs have the discretionary authority to independently make decisions on regulation and supervision. ${ }^{2}$ The question might therefore be asked: who, or what, do IRAs represent?

This question, however, is rarely posed in the literature on independent market regulation. Three scholarly approaches regarding the position of IRAs in today's capitalist democracies can be distinguished. First, in the "technocratic" approach, the legitimacy of IRAs is based on the quality of their policy outputs. Because of their independence and expertise, IRAs are supposedly capable of delivering results that are qualitatively better than those of traditional political or bureaucratic institutions. ${ }^{3}$ Secondly, in the "delegation"

1 Baldwin (2012); Levi-Faur (2011); Duijkersloot (2007); Coen (2005); Majone (1996).

2 Gilardi (2008); Verhey (2005); Zijlstra (2005); Thatcher (2002).

3 Maggetti (2010); Vibert (2007); Sosay (2006); Majone (1999). 
approach, IRAs are democratically legitimate because government and parliaments have delegated public powers to them, and keep them in check through mechanisms of accountability and control. IRAs act as "agents" for their political "principals."4 Thirdly, in the "relational" approach, IRAs are thought to derive legitimacy from their position in a field of public and private actors - including courts, businesses, and consumers - to whom they are responsive and whose opinions they balance when making decisions. This is variously described as "interactive" policy-making, "participatory" or "deliberative" governance, or "horizontal" accountability. 5

Of course, each approach can be normatively criticised, while the approaches at some point are incompatible. IRAs that are too much kept in check by elected politicians might not be independent enough to achieve higher-quality results, while too much cosiness with private actors might likewise harm their independent stature. ${ }^{6}$ Yet, despite these disagreements, adherents of all approaches in the literature seem to agree on one central tenet: that IRAs, because of their independence from political institutions and affected stakeholders, are "unrepresentative." According to the Swiss regulations scholar Fabrizio Gilardi, IRAs "do not conform to the representative model" 7 and according to Martino Maggetti they do "not rely on any claim of representativeness." are "non-majoritarian institutions" (NMIs), public bodies "that are neither directly elected by the people nor directly managed by elected officials." Since delegation to these independent bodies constitutes a transfer of powers "away from elected bodies to unelected ones,"10 they supposedly have a "non-elective and non-representative nature."1l Power in capitalist democracies has therefore shifted from democratic institutions to "unrepresentative" bodies such as IRAS. $^{12}$

In this contribution, I take issue with these statements about the unrepresentative nature of IRAs. While their establishment certainly constitutes a historic shift of decision-making power from elected to unelected bodies, this does not mean that IRAs have no representative claims. On the contrary: they do, and analysing the representative claims of IRAs is crucial to any evaluation

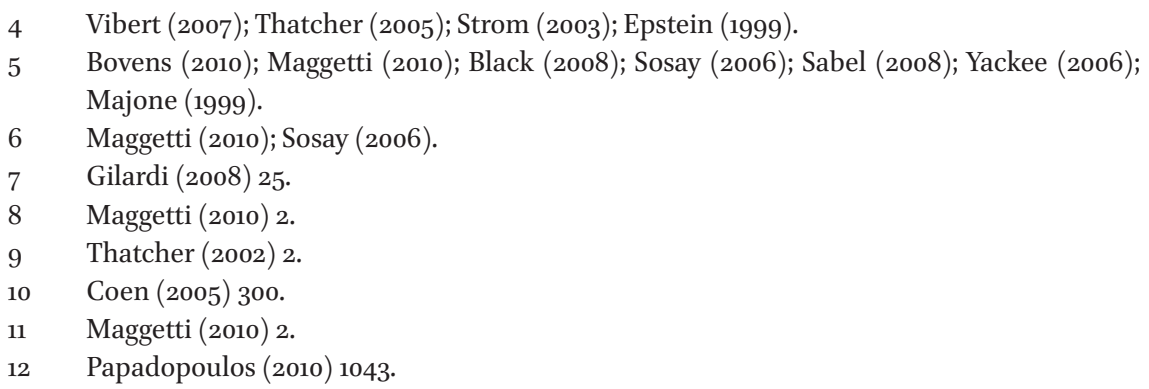


of their position in today's democracies. My analysis of the representative claims historically and presently made of, by, and around four IRAs in the Netherlands is based on recent advances in representation theory. In contrast to the literature on independent market regulation, in which "being representative" is equated with "being elected," representation theorists such as Michael Saward conceive of representation as a much more dynamic process. Representation is a discursive and performative process in which a claimant asserts that an entity stands or acts for a constituency - a claim that may or may not be accepted by an audience. Representation consists of the construction of a representative and "the represented" in an interactive relationship. ${ }^{13}$ This happens in parliaments, where elected politicians claim to represent popular constituencies; ${ }^{14}$ in civil society, where interest and protest groups do the same, ${ }^{15}$ and, so I will argue, in the world of independent market regulation. Recognising this provides insight into a crucial historical change to representative democracies, and is, I will argue, a contribution to the existing approaches to the position of IRAs in these polities.

In the following, I will first discuss the theory of representation developed by Saward in The Representative Claim (2010). Then, I will show how the heuristic tool of the "representative claim framework" (RCF) can be applied to IRAs, and discuss my case selection. Subsequently, using the RCF tool, I will demonstrate how four Dutch IRAs were claimed by elected lawmakers in the 1990s and 2000 s to represent - in a non-electoral, independent way - certain constructed constituencies on liberalised marketplaces. The four IRAs, I will then show, continued making representative claims after their establishment. Thirdly, I will show how the interaction between these IRAs and affected interests in consultation procedures constitutes a reciprocal process of representative claim-making and reception. Lastly, I will discuss the contribution of a representative claims analysis of IRAs to the three standard scholarly approaches to their legitimacy, and to our understanding of the historical change of representative democracies embodied by IRAs.

\section{Representation as a Process of Claim-making and Reception}

Representation is often equated with elections. A "representative democracy" according to many people is a political system in which a geographical and

\footnotetext{
13 Saward (2010; 2009; 2006; 2005).

14 De Wilde (2013); Severs (2010).

15 Marochi (2010).
} 
cultural constituency - the people of a nation - elects a parliamentary body (and perhaps a president) on the basis of the "one person, one vote" principle. Historically, however, the term representation was more broadly applied, ${ }^{16}$ and even today this remains so. Interest groups, social movements, independent ombudsmen, religious leaders, and celebrities all claim to represent constituencies, even though they are not elected. And often, their claims are accepted by democratic institutions and the public alike. Apparently, elections do not exhaust representation.

In The Representative Claim Saward offers a theorisation of representation as a discursive and performative process. It consists of a claimant asserting that an entity stands or acts for a constituency. An audience may or may not accept this representative claim. Representation is therefore dynamic, even ubiquitous: it happens across societies. But it is also unstable: audiences do not necessarily accept representative claims. This conceptualisation of representation sets it apart from earlier ones, in which representation was equated with institutional mechanisms like elections, or defined by normative values like political equality. ${ }^{17}$ In Saward's view, representation is a communicative, reciprocal process playing out between claimants and audiences.

Saward's conceptualisation opens up the political world at large for investigations into representative claim-making and reception. Political and societal institutions, mechanisms, and communicative processes can be investigated for representative claims made about them or in them. To this end, he offers the heuristic tool of the "representative claim framework" (RCF). In representation, a claim-maker (an individual or collective, 'M') presents a subject (itself, or some other individual or collective, ' $S$ ') as standing for or acting in the interests of an object (a creative depiction of a constituency and its interests, ' $\mathrm{O}$ '). Audiences ('A') may receive, evaluate, and decide whether to accept or reject a representative claim - and thus consider 'S' a representative. To the extent that audiences recognise themselves and their perceived interests as implicated in a claim, moreover, they may consider themselves a constituency (see Figure 10.1).

Representation conceptualised as such happens in many physical and virtual spaces: in the parliamentary arena, in the news media, at election meetings, at protest marches, in governance networks, and so forth. Makers make claims about institutions, about persons, about themselves, acting or standing for constituencies, vis-à-vis audiences (including potential constituencies). Representation is flexible: a claim-maker can offer him/her/itself as the representing subject, but also someone or something else. Representative claims can

\footnotetext{
$16 \quad$ Pitkin (1967) 2-4.

17 See: Pitkin (1967); Eulau and Karps (1977).
} 
A maker of representations ('M') puts forward a subject ('S') which stands or acts for an object (' $\mathrm{O}$ '), and is offered to an audience (' $\mathrm{A}$ ').

FIGURE 10.1 The representative claim framework (RCF) (adapted from Saward 2010: $3^{6}$ ). Note: In Saward's original model, a fifth element was included: the referent (' $\mathrm{R}$ '), or real-life entity of which the object is the representation. Since this entity is "unrepresentable" other than as a representation, however, I have dropped it from the framework. Saward (2010) 36-38.

be acts of self-representation and other-representation, while audiences can be multiple and diverse. They can consist of potential constituencies, as well as of outside observers.

Central to the dynamics between representative claim-makers and audiences are "cultural resources" and "constituency constructions." "Cultural resources," first, are employed by claimants to convince audiences (including potential constituencies) that they - or someone or something else - stand or act for someone or something else. Cultural resources can be conceptualised as the cultural meanings or normative principles that claimants and audiences must share in order for representative claims to be successful. ${ }^{18}$ For example: the transparency and regularity of elections based on the principle of "one person, one vote" constitute powerful cultural resources for politicians in their claims to represent constituencies. Most audiences in contemporary democracies will accept these claims. Yet alternative and additional cultural resources exist and are regularly employed, including non-electoral ones:

- Ombudsmen may claim that their very independence from politics and the bureaucracy enables them to represent the interests of citizens vis-à-vis the administration;

- Interest groups or trade unions may claim that intra-organisational authorisation and accountability mechanisms connect them to their memberships, and that they therefore represent these constituencies;

- Climatologists or other specialists or professionals may claim that their expertise lends them authoritative insight into the "real" interests of a group or collective, and that they can therefore speak for or on behalf of them;

- Minority politicians, religious leaders or monarchs may claim that their identity connects them to their community, and that they therefore represent it;

$18 \quad$ Saward $(2010) 75$. 
Constituency construction is a second crucial element of representative claimmaking. Collective identities are never "natural" or "given," but always constructed in a socially discursive process. ${ }^{19}$ Representative claim-makers make assertions about the identities and interests of the constituencies purportedly represented by them or others. They may paint constituency identities and interests precisely ("I represent the membership of the national association of dentists" or "the Turkish minority of Rotterdam") or vaguely ("I speak for the common people" or "the public"). Representative claim-making is a creative and aesthetic process.

Audiences, on their turn, employ cultural resources and evaluate constituency constructions to decide whether to accept or reject representative claims. The "success" of a representative claim largely depends, first, on the "match" between the cultural resources employed by claimants and those employed by audiences. A protest leader may, for example, not be considered a "true" representative by the news media, because he/she is not authorised by a constituency. Audiences, secondly, also have to recognise the constituency constructions of representative claim-makers as somehow accurate. Someone who does not consider himself a member of a downtrodden minority will likely not feel represented by this minority's purported spokesperson. Audiences may actively contest the claims of representative claim-makers, and offer an alternative picture of a constituency's identity and interests. In doing so, audience members become representative claim-makers themselves. ${ }^{20}$

Representative claim-making so can take many forms: electoral and nonelectoral, formal and informal, explicit and implicit. Political rhetoric and debate often contain claims about institutions, organisations, or individuals being the best spokespeople or guardians for constituencies - because they are authorised by them, or, on the contrary, are independent from them. And these constituencies and their interests are necessarily discursively constructed - although they may be perceived as more or less accurate by audiences. Whether audiences and/or constituencies accept them, is another question.

According to Saward, neither cultural resources nor the accuracy of constituency constructions determine whether a representative claim should be considered democratically legitimate. Representative claims should be considered democratically legitimate when constituencies that a claimant intends to represent actually feel represented. In an open society, the demonstrable acceptance by this appropriate constituency of a representative claim about them - backed up by whatever cultural resources claimants employ, and

19 Saward (2010) 49, 74; cf. Ankersmit (1996); Anderson (1986).

20 Saward (2010) 48-56. 
constituencies accept, be they elections, authorisation and accountability mechanisms, notions of shared identity or of substantive expertise - should count for the democratic legitimacy of this particular claim. ${ }^{21}$ Saward argues that it is up to researchers to investigate who makes representative claims, what their contents are, how they are received, and why they are accepted or rejected.

\section{Studying Representative Claims in Regulatory Governance}

IRAs are among the most powerful public authorities today. Their decisions in liberalised marketplaces affect millions of businesses, professionals, and consumers, and involve billions of euros and dollars. Yet they are anomalies in the "textbook model" of representative democracy: their decisions are not fully controlled ex ante by either affected stakeholders or by democratic institutions such as governments and parliaments. This has led many researchers to consider IRAs "unrepresentative." But are they? I argue they are not, and to support this argument I will perform a representative claims analysis on a selection of IRAS.

The four IRAs examined in this article are Dutch. The Netherlands is an interesting country setting for this project. Compared to other continental European countries, the Netherlands have since the 1980 os been at the vanguard of liberalisation and privatisation policies in such domains as telecommunications, energy, railways, and healthcare. ${ }^{22}$ The same goes for the delegation of public powers to independent agencies ("agencification"): Dutch IRAs by now are not as independent and powerful as their American or British counterparts, but more so than in most European countries. ${ }^{23}$ IRAs have since the 1990 s become a prominent feature of the Dutch governance system and have in recent years been the subject of controversy. ${ }^{24}$ Hence it is very interesting to investigate who, or what, these unelected bodies (claim to) represent.

To ensure external validity with the population of IRAs at large, four Dutch cases were selected that were (a) formally independent from both the political sphere and affected interests (b) involved in market regulation (c) a public authority. To reflect variety in the wider population of IRAs, cases were selected

\footnotetext{
$21 \quad$ Saward (2010) 146-48.

22 Dan et al. (2012); Stellinga (2012).

23 Gilardi (2008) 59.

24 Van den Berg (2012); Van Gestel, Eijlander, and Peters (2007).
} 
that operated in different economic domains, and had different goals and competences. This resulted in the following selection:

- the Onafhankelijke Post en Telecommunicatie Autoriteit 'Independent Mail and Telecommunications Authority' (OPTA): the Dutch telecommunications regulator from 1997 to $2013,{ }^{25}$

- the Nederlandse Mededingsautoriteit Energiekamer 'Netherlands Competition Authority Energy Chamber' (NMa Energy Chamber): the Dutch energy regulator from 1998 to $2013,{ }^{26}$

- the Autoriteit Financiële Markten 'Financial Markets Authority' (AFM): the Dutch financial markets supervisor since 2002;

- the Nederlandse Zorgautoriteit 'Netherlands Healthcare Authority' (NZa): the Dutch healthcare market regulator since 2006

Representative claims about and by these four IRAs were studied in the following way:

To study representative claims about these four IRAs, acts of establishment and related parliamentary debates were studied. These were expected to contain constructions of the IRAs as subject ('S'): bodies with a certain nature or properties, which enable it to act or stand for certain constituencies as object ('O'). These constituencies, likewise, are creative depictions of people as having a certain nature or interests. The makers ('M') of these representative claims are governmental and parliamentary lawmakers. In laws and debates, lawmakers publicly elaborate on the nature of IRAs and the constituencies they act or stand for. The Dutch citizenry may be considered the general audience ('A') of these claims. ${ }^{27}$ Legislative representative claims about IRAs can be considered the "constitutive" representative claims of the independent bodies: henceforth they embody these.

To study representative claims by the four selected IRAs, their websites, annual reports, and policy documents were studied. These, too, were expected to contain constructions of the IRAs as subject ('S'): bodies that act or stand for certain constructed constituencies as objects ('O'). Now, however, the makers

25 In 2013, OPTA was merged with the competition authority Nederlandse Mededingingsautoriteit (NMa) and the Consumentenautoriteit 'Consumer Authority' to form the Autoriteit Consument and Markt 'Consumer and Market Authority' (ACM).

26 In 1998, this IRA was established as the Dienst uitvoering en toezicht Elektriciteitswet (DTe). In 1999, it became a chamber of NMa. From 2008 onwards, it was called NMa Energiekamer until the 2013 merger into АСм.

27 Potentially, audiences can be multiple and diverse. Since the intention of a claim-maker is not always clear, however, here the Dutch citizenry is considered the audience. 
('M') of these representative claims are the IRAs themselves. In the public sphere, the independent bodies craft an image of themselves and the constituencies they claim to act or stand for. The Dutch citizenry, but also affected interests such as businesses and professionals, may be considered the audience ('A') of these representative claims. ${ }^{28}$

To study representative claims in the policy-making processes of the four IRAs, lastly, consultative procedures were studied. IRAs regularly consult affected interests before making decisions: corporations, professional groups, and consumer organisations who claim to have a stake in the outcome. ${ }^{29}$ These consultative procedures were expected to involve a reciprocal process of representative claim-making and reception: assertions by IRAs and lobbyists alike about which constituencies and interests would be served by IRA decisions. Yet these consultations are not public, and therefore recourse was taken to 20 in-depth interviews with IRA staffers and 25 with lobbyists. This allowed insight into the representative claim-making strategies both IRAs and affected interests regularly employ when deliberating about regulatory decisions.

Except for the last section, the reception of the representative claims about and by IRAs was not studied. This would have involved survey research among the Dutch public. The following is therefore a qualitative account of representative claim-making in regulatory governance.

\section{Representative Claims about IRAs: Representing Public Interests}

The establishment of IRAs in the Netherlands followed the marketisation of economic and societal domains and the agencification of government organisations since the 1980 s. $^{30}$ From the early 1990 onwards, Dutch lawmakers liberalised and marketised the telecommunications and energy sectors. State companies were gradually privatised, while new competitors were allowed. From the 200os onwards, Dutch lawmakers enacted new regulations for the financial sector, while they liberalised and marketised the healthcare sector. ${ }^{31}$ In all these sectors, lawmakers established IRAs: regulatory bodies whose decisions would not be fully controlled ex ante by affected stakeholders or democratic institutions. Which representative claims did lawmakers make about these new bodies?

28 Once more, however, intended audiences are difficult to pinpoint, and this will not be attempted.

29 Lavrijssen (2006); Yackee (2006).

$30 \quad$ Stellinga (2012); Verhey (2005); Van Thiel (2000).

31 Stellinga (2012). 
The representative claims about the first generation of IRAs were rather general. Dutch lawmakers (makers) in 1997-1998 argued that the telecommunications regulator OPTA was to be temporarily independent from the political sphere because the state still had financial interests in the former state company KPN. OPTA was to be impartial, its decisions solely based on "expertise" (subject).

The societal and economic interest (object) involved in the tasks is best served [...] with a division of tasks between a minister and an armslength specialized administrative organ $($ subject $) .{ }^{32}$

Lawmakers claimed that the economic interest served with OPTA's tasks was the "competitiveness of the Netherlands" (object), to which telecommunications liberalisation would contribute. ${ }^{33}$ As an independent "guardian of general societal and consumer interests" (object), ${ }^{34}$ moreover, opTA (subject) would "protect" universal access to basic telecom services, freedom of choice for users, privacy, and state security. ${ }^{35}$ Lawmakers thus claimed that OPTA, through its independent decisions - made beyond the purview of stakeholders and democratic institutions - would act in the interests of the Dutch economy and society. This was a representative claim, if a rather general one. The energy regulator DTe in 1998, meanwhile, was only made independent de facto, while Dutch lawmakers in the legislative package simply stated that energy liberalisation would give "customers and suppliers" more "freedom of choice."36 Since lawmakers expected telecom and energy liberalisation to be accomplished quickly, they considered these IRAs temporary, exceptional bodies. ${ }^{37}$ Their transitional nature apparently required no representative claims other than rather unspecific ones.

This changed around 2000, however, when criticism of the liberalisation and marketisation policies of the past decades erupted. Important Dutch advisory bodies such as the Raad van State 'Council of State' and the Wetenschappelijke Raad voor het Regeringsbeleid 'Scientific Council for Government Policy' (WRR) stated that after years of liberalisation policies, the balance with societal "interests" like the continuous availability, quality, and reasonable price of goods and services had to be rethought. The WRR wrote that Dutch lawmakers

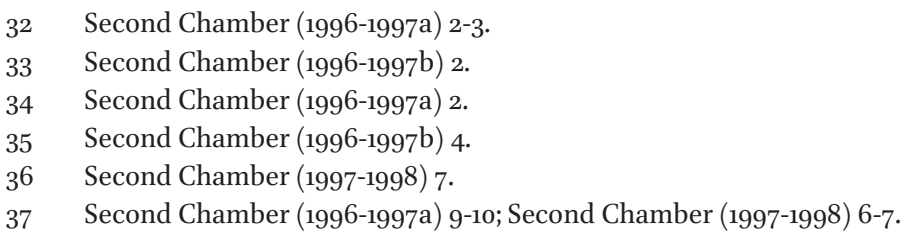


"too often too unthinkingly and too unprepared had made a choice for marketisation, without having been sufficiently aware of the (necessity of guaranteeing) the public interests at stake." ${ }^{38}$ Both advisory bodies called for an enhanced role of IRAs in this respect. And the Dutch government responded, making more specific and consistent representative claims about the unelected bodies.

The government, in a series of reports in 2001-2004, wrote that the elected political sphere - parliament and government - had to retain an important role in guaranteeing so-called "public interests" in liberalised domains. This rhetorical construct was new to Dutch political discourse at the time. Until then, the term "general interest" was often employed when referring to state intervention in economic domains, for instance to deliver goods and services to citizens via state companies. ${ }^{39}$ Now, the term "public interests" became current, to signify concrete desiderata (interests) in economic and societal domains, and the exact beneficiaries (constituencies) of these desiderata. The Dutch government considered a well-functioning liberalised marketplace and transparent consumer information economic public interests, belonging to people constructed as producers and consumers. Universal service provision and the quality and safety of networks it also considered non-economic or societal interests, belonging to people constructed as citizens. ${ }^{40}$ With this distinction, the government picked sides in a debate between competing schools of thought about regulatory rationales and constructed a constituency to be represented by IRAS.

Around 2000, one school of Dutch policy advisors held that ongoing marketisation policies necessarily were in the general interest, as they enlarged economic welfare. They depicted the beneficiaries of these policies strictly as producers and consumers. Only economic analysis could, in their view, determine whether any public interests other than free markets existed. ${ }^{41}$ Another school, however, represented by the WRR, held that multiple rationales for determining public interests existed, one of them being citizenship rights: the right of every citizen, notwithstanding economic position, to certain goods and services. In their view, it was up to parliament to determine public interests - aided by economic analysis, but not exclusively so. And IRAs, according to the WRR, had an important role to play in independently guaranteeing and

38 Wetenschappelijke Raad voor het Regeringsbeleid (WRR) (2000) 162; cf. Raad van State (2000) 49-50.

39 De Pree (2008) 289-92.

40 Second Chamber (2003-2004a) 2-6.

41 Teulings (2003); De Pree (2008) 312-313. 
furthering economic and societal public interests in liberalised domains. ${ }^{42}$ The WRR called upon Dutch lawmakers to henceforth more explicitly formulate within regulatory legislation which interests of the public were at stake in liberalised domains, and how IRAs were to independently guarantee or further these.

Dutch lawmakers did exactly this in the early years of the twenty-first century. First of all, they gave a new interpretation to the capacities of IRAs that so they claimed - allowed them to represent public interests. In 1997-1998, the early regulatory bodies OPTA and DTe had only hesitantly been hived off from ex ante political control because the state's ownership of telecom and energy companies required it. After 2000, Dutch lawmakers started to frame independence as an inherently desirable trait - a cultural resource that allowed the bodies to act or stand for public interests in a way the elected political sphere could not. IRAs in a 2001 report were called "indispensable" because they were "objective," "professional," and "fact-based."43 When establishing the AFM in 2001 - an independent regulatory body in the financial sector, a domain in which the state did not have direct financial interests - lawmakers stated its independence was of "unabated value" to "expertise-based supervision." ${ }^{44}$ And in 2004, the Dutch government proclaimed the independence of IRAs from politics an "uncontested" principle because it meant being removed from "today's thinking in politics." ${ }^{45}$

Secondly, Dutch lawmakers after 2000 more clearly delineated which publics and interests IRAs were to independently stand and act for. In 2004, they (maker) made the representative claim that a new and revamped OPTA (now independent for the near future and with expanded regulatory powers) would, on the basis of its expertise (subject), "further the interests of end users (object) in terms of choice, price and quality" of telecommunications. ${ }^{46}$ In its decisions on market entry, universal provision, and privacy, it would place the "interests of citizens and businesses" (object) in the telecom sector at its heart. ${ }^{47}$ That same year, Dutch lawmakers also made the representative claim that NMa Energy Chamber, now fully independent, would in its expertise-based decisions secure the "public interests" of energy consumers, businesses, and citizens in a competitive, non-discriminatory, and transparent marketplace,

\footnotetext{
42 WRR (2000).

43 Second Chamber (2000-2001) 12.

44 Second Chamber (2001-2002) 35.

45 Second Chamber (2003-2004a) 8.

46 Telecommunications Act Revision Act 2004 Art. I art. 1-3.

47 Second Chamber (2002-2003) 11.
} 
with quality networks and supply security. ${ }^{48}$ In 2006 , Dutch lawmakers made the representative claim that AFM in its expertise-based decisions, made independently from political and stakeholder control, would "guard" and "further" the "public interests" of financial businesses and consumers in an orderly, transparent financial marketplace marked by careful customer treatment. ${ }^{49}$ And Dutch lawmakers in 2006 made the representative claim that the independent healthcare authority NZa in its expertise-based decisions would secure the public interests of the Dutch citizenry in the accessibility, affordability, and quality of marketised healthcare. ${ }^{50}$

After 2000, lawmakers specifically emphasised the public interests of one specific (constructed) constituency: consumers. They claimed that OPTA and Energy Chamber would further the interests of consumers in free choice and market transparency. ${ }^{51}$ AFM's supervision was targeted at the "self-responsible consumer," who nevertheless required careful treatment. ${ }^{52}$ The NZa was legally obligated to "put the general consumer interest first" in its duties. ${ }^{53}$ And when OPTA, NMa and a third IRA - the Consumer Authority - were merged in 2013, this was claimed to be in the "interest of the consumer." ${ }^{24}$ By then, Dutch lawmakers had established a host of institutions which were claimed on the basis of their expertise to represent the interests of various publics: businesses, consumers, and citizens. The IRAs would do so independently from democratic institutions and affected stakeholders.

\section{Representative Claims by IRAs: Protecting and Emancipating Consumers}

Since their establishment in the late 1990s and early 2000s, the four IRAs themselves have consistently reproduced these representative claims. On their websites, in annual reports, and in policy documents, they present(ed) themselves as independent and expert bodies. OPTA (maker) presented its ability to make independent decisions as a matter of "integrity" (subject); $; 5 \mathrm{NZa} \mathrm{(maker)} \mathrm{pres-}$

\footnotetext{
48 Second Chamber (2003-2004b) 1; cf. ibid. 1-5.

49 Second Chamber (2003-2004c) 28-30.

$50 \quad$ Second Chamber (2004-2005) 5-7.

$51 \quad$ Second Chamber (2002-2003) 11; idem (2003-2004b) 6.

$5^{2} \quad$ Second Chamber (2001-2002) 14.

53 Healthcare Market Structuring Act 2006 art. 3-4.

54 Consumer and Market Authority Establishment Act 2013.

55 ОРтA (2013a).
} 
ents itself asindependent "market master," "supervisor," and "advisor" (subject). ${ }^{56}$ NMa (maker) on its website emphasised that it employed about 400 "highly educated people" (subject). ${ }^{57} \mathrm{NZa}$ (maker) claims that acting on the basis of "expertise" (subject) is one of its "core values." 58 But over the years, the IRAs have also begun to emphasise another quality: their communicativeness, especially vis-à-vis businesses and professional groups. OPTA publicly invited sectoral interests to "think along" and "exercise influence"; 59 AFM emphasised its "dialogue" with financial interests, the political sphere, and the general public; 60 NZa stresses it performs its tasks "together with" the healthcare sector. ${ }^{61}$ Being communicative now constitutes part of the representative claim of IRAs.

All four IRAs in their public presentation also have constructed constituencies in whose interests they claim to make their independent decisions. AFM (maker), in its annual reports, has depicted financial market participants, consumers, the general public, and the state (objects) as beneficiaries of its independent supervision of the financial sector. ${ }^{62} \mathrm{NMa}$ and AFM (makers), during the financial crisis of 2007-2008, (re)presented themselves (subject) as "restorers" of the Dutch public's (object) trust in free markets. ${ }^{63} \mathrm{NZa}$ claims with its independent decisions to represent "three public interests (object) in healthcare": accessibility, affordability, and transparency about quality. ${ }^{64}$ Economic actors on free marketplaces and public interests figure prominently as constructed constituencies in the representative claims of the four IRAs about themselves, like they did in the original claims of lawmakers.

Over the years, moreover, the four IRAs have especially emphasised how their regulatory activities are "in the interest of the consumer." 65 In 2005, OPTA stated it would primarily pursue the consumer interest by stimulating market competition. ${ }^{66}$ A year later, both market competition and consumer protection were stated to be the IRA's mission; ${ }^{67}$ and in 2008 , the consumer interest was claimed to be central to OPTA's activities, its annual report laced with pictures of consumers (see Figure 10.2).

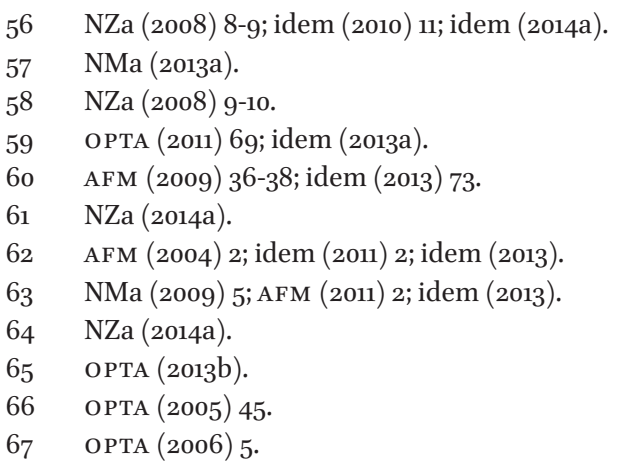




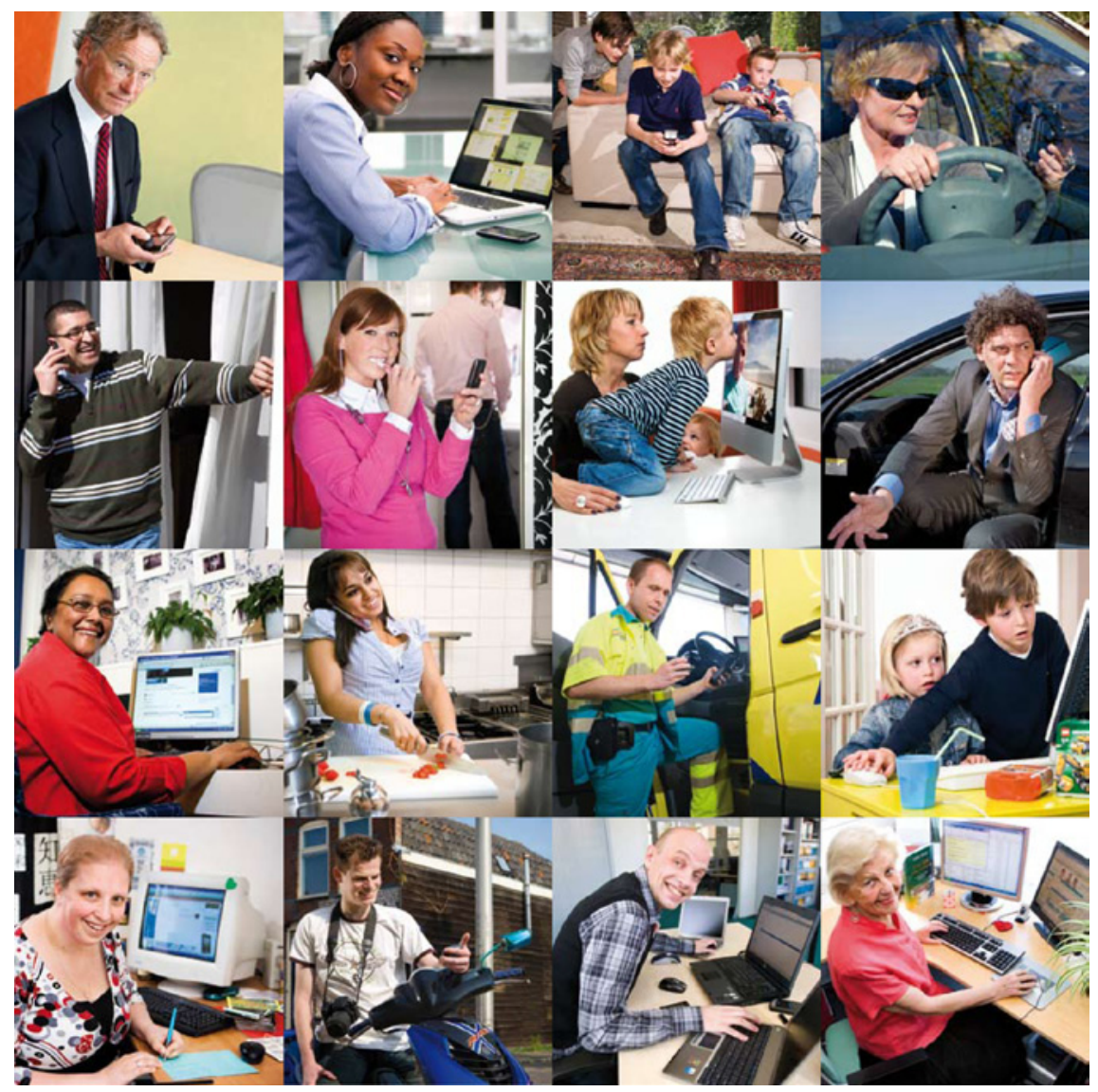

FIGURE 10.2 OPTA depicts its constituency in its annual report. Source: OPTA, Jaarverslag 2008 [accessed online 6.2.2019: <https://www.acm.nl/sites/default/files/ old_publication/publicaties/9795_jaarverslag-opta-2008.pdf>].

Likewise, NMa and its Energy Chamber in 2013 claimed: "All our efforts are aimed at benefits for the consumer." Its "ultimate goal" was to "create as many economic benefits to consumers as possible." ${ }^{68} \mathrm{NZa}$, for its part, on its website explained its corporate logo (see Figure 10.3) - a "modern guardian angel" - in the following way:

This angel symbolizes the protective role of the NZa regarding the interests of the healthcare consumer. At the same time the angel symbolizes the authority and expertise of the NZa, by which it gives insurers and 


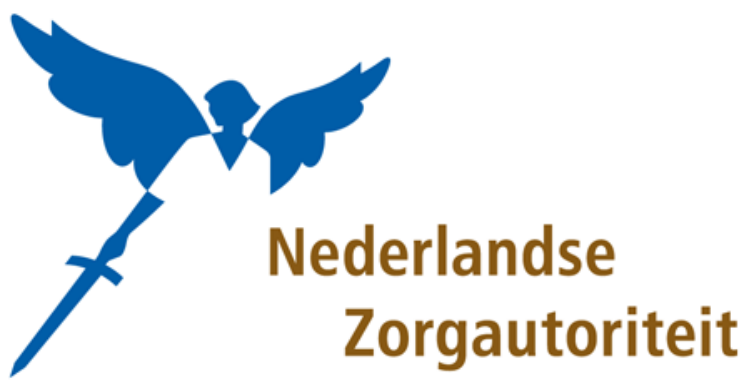

FIGURE 10.3 NZa corporate logo. Source: NZa annual report 2010.

practitioners the right incentives to provide the consumer with efficient and good healthcare. ${ }^{69}$

In addition to making consumers a key element in their public self-presentation, the four IRAs have started to directly engage this constituency as well. From 2007 onwards, OPTA and NMa Energy Chamber on their website ConsuWijzer offered consumers "transparent" and "comparable" information on telecommunications and energy providers. ${ }^{70}$ They also collected consumer complaints, claiming - if enough of them were received - to directly intervene in the sectors "to improve the position of the consumer."71 The two IRAs have thus depicted themselves as responsive bodies, willing to intervene in marketplaces on behalf of consumer interests. Likewise, AFM's post-2010 supervisory project "Putting the customer's interest first" was to stimulate financial corporations to give consumers transparent information on the risks of financial products. This was to give the consumer "what he needs" rather than "what he wants" (original emphases). ${ }^{72}$ AFM so portrayed itself as a representative of consumers with insight in their "true" needs.

Vis-à-vis the consumer constituency, the four IRAs have employed a discourse of tutelage and emancipation. OPTA and NMa Energy Chamber claimed ConsuWijzer "strengthens the consumer" and "strives to make the consumer assertive" by giving him tools to "get to work": model letters of complaint, scripts to practice conversations with shopkeepers, and an online coach to stimulate consumers to switch energy providers. ${ }^{73}$ Likewise, AFM on its web-

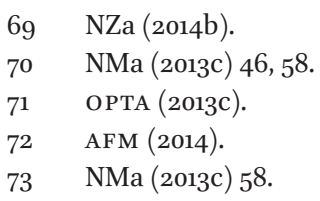


site offers games such as "More choice with money" and "One euro is not the same as another euro" to teach consumers how to make "rational" money choices.

The IRAs have thus depicted consumers as in need of information and critical skills, and portrayed themselves as their representatives who provide information but also teach them to help themselves. In this way, the IRAs have taken an active role in constituency construction: in transforming citizens into consumers on liberalised marketplaces.

\section{Representative Claim-Making and Reception in IRA Policy-Making Processes}

IRAS regularly consult affected interests before making decisions: corporations, professional groups, and consumer organisations who claim to have a stake in the outcome. ${ }^{74}$ But what role do the representative claims about and by IRAs play in consultative procedures? As these consultations in the Netherlands are not public, interviews were held with regular participants in these procedures: 20 IRA staffers and 25 affected interest lobbyists in the four domains. ${ }^{75}$ First, however, I will discuss which affected interests take part in IRA consultations, and why.

\section{$1 \quad$ Who Has Access to Consultations?}

The consultative procedures of Dutch IRAs are not universally accessible. The four IRAs, as prescribed by Dutch administrative or regulatory law, but also of their own volition, determine who has access to these procedures on the basis of criteria to judge the claims of external parties to represent affected interests. When prescribed by law, these criteria determine inclusion on the basis of the "personal," "distinctive," "objective," and "relevant" materiality of the interest at stake in a decision. ${ }^{76}$ On this basis, OPTA and NMa Energy Chamber allowed telecommunications corporations such as KPN and Vodafone, energy network operators such as Liander and Stedin, energy production and supply companies such as Nuon and Eneco, interest groups such as EnergieNed and Netbe-

\footnotetext{
74 Lavrijssen (2006); Yackee (2006).

75 Interviews were conducted between 2010 and 2014. The questionnaire can be found in my dissertation, Regulation without Representation?, which is publicly available at $<\mathrm{https}$ :// dspace.library.uu.nl/handle/1874/306252>. Interview transcripts are available at request.

76 Lavrijssen (2006) 30-31; De Poorter (2003) 131-32. This may include organisations that represent the "general and collective interests" of others, such as interest groups and consumer organisations.
} 
heer Nederland, and organisations for large-scale industrial energy consumers into their consultative procedures. ${ }^{77}$

AFM and NZa have drawn up additional criteria to evaluate the claims of external parties to represent affected interests. Parties admitted to AFM consultative procedures must "faithfully represent" interests in the financial sector, ${ }^{78}$ while those admitted to NZa consultations must conform to certain criteria for democratic representation. Healthcare interest groups, for example, must have elected boards and be accountable to their members. ${ }^{79} \mathrm{On}$ this basis, at AFM, big banks such as ABN AMRO and ING, and about twenty financial interest groups for bankers, accountants, and big and small investors are represented in consultative procedures. ${ }^{80}$ At NZa, about thirty interest groups for healthcare insurers, hospitals, medical specialists, dentists, general practitioners, and the like are represented. ${ }^{81}$

Finally, IRA staffers sometimes decide on inclusion in an ongoing fashion without clear criteria. Many interviewed staffers and interest group lobbyists have mentioned that regulatory governance in the Netherlands is a "small world." IRA staffers and lobbyists "know whom to call" when input seems required. ${ }^{82}$ Consumer organisations such as Consumentenbond 'Consumer's League', Vereniging voor Effectenbezitters 'Stockowners Association' (VEB), and patient groups such as the Nederlandse Patiënten Consumenten Federatie 'Dutch Patient Consumer Federation' (NPCF) usually are invited, but often lack the financial means, expertise, or the supposed direct interest in the decisions at hand to send delegates. ${ }^{83}$

During the consultative procedures, when proposed IRA decisions are discussed, a reciprocal process of representative claim-making and receiving takes place. Affected interest lobbyists must represent the material and financial interests of their employers, but as claim-makers, make creative constructions of the interests involved. IRA staffers, on their turn, as audiences evaluate these representative claims, but their reception is informed by the representative claims of the IRAs as institutions. Four representative claim-making strategies and patterns of reception can be discerned.

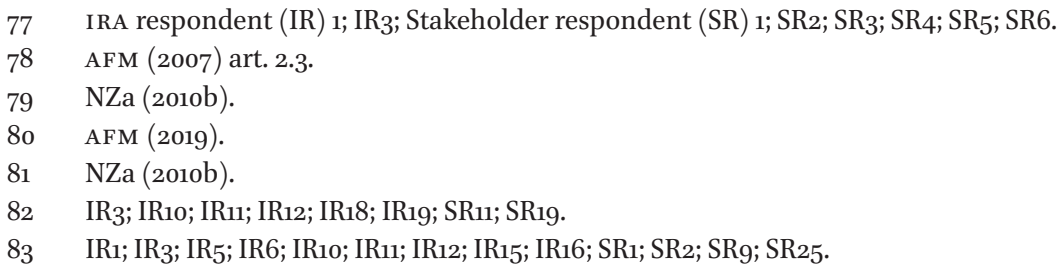


Four Strategies of Representative Claim-making and Their Reception

IRA staffers do not appreciate lobbyists all too overtly acting as lobbyists: as representatives of the direct, material interest of their corporations or professional groups. ${ }^{84}$ Of course, lobbyists are only allowed to the table because they represent such an interest (see above), and they may certainly state a proposed IRA decision is (not) in the direct, material interest of their constituency. As a telecom lobbyist says about consultations on fiberglass regulations: "In this game, our song is: 'We always get too little." 85 An opTA staffer confirms: "These are commercial parties with commercial interests. They will say so, and we know they will say so. So nobody is fooling anyone." ${ }^{86}$ But many interviewees do not consider self-interest based lobbying a very effective strategy, even though it is very convincing as a representative claim. According to a medical specialists' lobbyist, "if you only represent naked interests, you are not going to make it." ${ }^{87}$ An AFM staffer confirms: "If you are too obviously agitating on the basis of your own self-interest, you are automatically not going to be very effective." 88 Because IRAs and their staffers have broader interest claims, they, like lobbyists, need to translate their arguments to these broader interests.

According to interviewees, it is more effective for lobbyists to claim to represent the direct, material interests of multiple corporations or professional groups. 89 "When interests run parallel, we act together," says one telecom lobbyist. ${ }^{90}$ IRAS and their staffers seem more receptive to viewpoints on proposed decisions that are shared by multiple corporations or professional groups. One healthcare insurers' lobbyist says: "The NZa is sensitive to joint solutions. When all parties together say an alternative is better, the NZa is sensitive to that." ${ }^{91}$ An OPTA staffer reflects: "We encountered so much resistance from all market parties to a hypothesis that we reconsidered. Despite us knowing they of course have a certain interest. All parties were united there."92 But IRA decisions are often zero-sum games: they harm certain business interests while benefiting others. Therefore, acting in concert is often no option for affected interest lobbyists. ${ }^{93}$

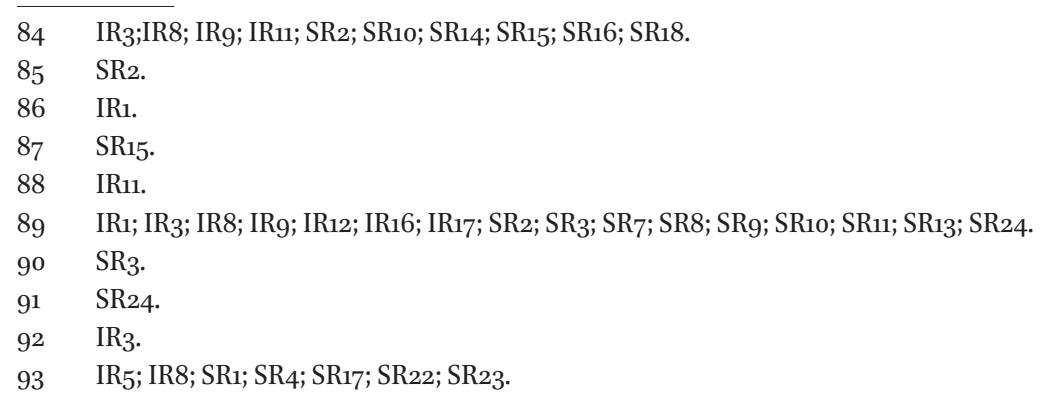


A third, more effective strategy for lobbyists, then, is to argue that proposed IRA decisions harm or benefit public interests, such as efficient marketplace competition, transparent consumer information, or the quality of networks. According to interviewees, IRAs and their staffers appreciate it when lobbyists frame their position on proposed regulatory decisions in terms of public interests. ${ }^{94}$ One dentists' lobbyist says: "We represent the interests of dentists, of course, but we are not going to make it by that alone. So we always have to translate [our policy proposals] to the patient's perspective and demonstrate it is also in the interest of the patient." ${ }^{\prime 5}$ One medical specialists' lobbyist says: "You always have to appeal to a societal interest, a patient interest. That is a strong card to play."96 These broader interests, after all, are the interests the IRAs claim to represent, and form a framework in which decisions are made. "[In specific IRA proposals] sometimes the emphasis is more on affordability, sometimes on accessibility. But in the end, you want to represent all those interests," one NZa staffer says. ${ }^{97}$ One AFM staffer says: "We consider ourselves very much the guardian of the consumer and the investor. In economic theory, we are the agent of the investing consumer who cannot obtain redress himself." ${ }^{\text {" A }}$ And one dentists' representative says about NZa: "They approach everything from the consumer interest. So when you file a proposal, you always have to emphasise the patient perspective." 99

Yet, since lobbyists are only allowed to consultations because they represent the material interests of their employers, their claims to represent wider constituencies - the sectoral marketplace, their customer base, the public, consumers, citizens - are not entirely credible. They are, after all, not authorised by this wider constituency. Affected interest lobbyists all give their own renditions of the "consumer interest": healthcare insurers, for instance, stress the interests of policyholders, while healthcare practitioners emphasise the needs of patients. Consumer or patient organisations themselves, meanwhile, are often absent from consultations, even though they are invited. In the words of one dentist's lobbyist: "The patient himself plays no part in the entire story."100 One Energy Chamber staffer says: "We miss their counterforce in the consultations we arrange." 101

$\begin{array}{ll}94 & \text { IR6; IR7; IR8; IR10; IR11; IR14; IR17; IR18; SR15; SR18. } \\ 95 & \text { SR18. } \\ 96 & \text { SR15. } \\ 97 & \text { IR18. } \\ 98 & \text { IR10. } \\ 99 & \text { SR18. } \\ 100 & \text { SR18. } \\ 101 & \text { IR16. }\end{array}$


A fourth strategy for lobbyists, then, is not to present themselves (only) as public or consumer interest representatives, or as corporate lobbyists, but as "experts" and "specialists." In support or as a substitute of representative claims, lobbyists put forward "hard" evidence about the effects of proposed IRA decisions. According to interviewees, IRA staffers appreciate empirical analyses and clear-cut descriptions of problems and solutions above lobbyists "preaching to the choir" or riding "hobby horses" about direct, material interests. ${ }^{102}$ One telecom lobbyist says: "Putting forward knowledge can influence the decision-making process. (...) The more compelling you make it, the harder it is to refute."103 An Energy Chamber staffer confirms: "If you can base your argument on statistics, that is an enormous aid."104

Yet despite their appreciation of lobbyists delivering factual information, IRA staffers remain aware that, for these representatives, interests are at stake. In the words of one AFM staffer: "Lobby and expertise sometimes blend into each other." ${ }^{105}$ Lobbyists freely admit that for them, supplying expertise and representing interests are intertwined. "You argue on the basis of methods. But you do that in your role as interest representative," says a dentists' lobbyist. ${ }^{106}$ Even in consultation procedures that are ostensibly about technical details and the "best" solution, lobbyists seek to represent constituency interests: "Here, you help to think substantively as a system expert, but you naturally also advocate your interest. It is a combination," says a lobbyist for medical specialists about NZa technical consultations. ${ }^{107}$ One lobbyist for industrial energy consumers reflects that in regulatory governance:

There is no such thing as value-free knowledge. Everyone works from his own perception, and those are partly coloured by the interests you represent. By whom you are paid, and by whom you are steered. ${ }^{108}$

IRA consultation procedures therefore are a "theatre" of representative claimmaking. All participants know that for lobbyists, the material interests of corporations and professional groups are at stake. Yet, IRAs and their staffers appreciate it when lobbyists translate their arguments to broader (public or consumer) interests, or act as experts - even though they retain a healthy

\begin{tabular}{ll}
\hline 102 & IR11; IR13; cf. IR1; IR2; IR3; IR5; IR8; IR9; IR10; IR11; SR1; SR2; SR3; SR4; SR15; SR16; SR19. \\
103 & SR2. \\
104 & IR9. \\
105 & IR11. \\
106 & SR18. \\
107 & SR15. \\
108 & SR19.
\end{tabular} 
scepticism about these representative claims. They appreciate the effort because they themselves claim to represent public interests, in an expertisebased manner.

IRA staffers nevertheless claim to have a number of strategies to try and separate useful "facts" from self-interested viewpoints. The first of these is to apply professional skills. An OPTA staffer says about information put forward by lobbyists: "There's always an interest behind it, yes. But it's kind of your job to see through that."109 Another OPTA staffer says: "It is the core of what we do at OPTA: weighing these kinds of insights and weighing the interests behind them."110 Applying "checks and balances" to information put forward by lobbyists is part of this professional skill. Another strategy of IRAs is to channel interest representation and "technical" deliberations into different consultative procedures. At the NZa advisory committees, lobbyists are expected to act on the basis of constituency interests, while in NZa technical consultations, they are to act as technical specialists. Yet, says one hospital's lobbyist, "everybody knows interests are represented there."111 In the end, however, all the input from consultations is sent to the IRA board, which takes a decision - although according to many interviewees, how they do this is not always transparent. ${ }^{112}$

IRA staffers value the involvement of lobbyists in regulatory decision-making: not only because they view interest representation in regulation as an inherently legitimate activity, but also because it provides them with important empirical information. Consultations, moreover, create understanding and sometimes support for IRA decisions, which facilitates compliance. ${ }^{113}$ Yet, the "over-representation" of corporate and professional lobbyists and the "underrepresentation" of consumer groups according to some create dangers of informational dependency and bias. ${ }^{114}$

\section{Discussion and Conclusion}

In this article, Saward's representative claim framework (RCF) has been employed to study representative claims about, by, and around four IRAs in the Netherlands. It has been demonstrated that these independent agencies were politically and legislatively claimed, and publicly claim themselves to

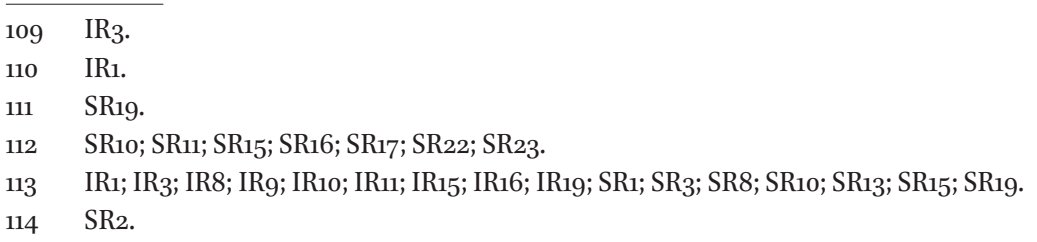


represent economic and societal public interests, including the consumer interest, in marketised and liberalised domains. The IRAs reproduce these representative claims, and have over the years increasingly emphasised their purported role as consumer protectors and emancipators. And the IRAs allow for a representation of affected interests in consultative procedures - albeit with a notable absence of consumer organisations - that constitute an important part of their decision-making processes. The statement that IRAs "do not rely on any claim of representativeness"115 is therefore refuted. IRAs embody, reproduce, and facilitate claims about the public and consumer interests they non-electorally represent on liberalised marketplaces.

What is the added value of a representative claims approach to IRAs? I will first discuss this in relation to the three dominant approaches to the position of IRAs in representative democracy. I will also consider the historical relevance of my argument. Lastly, I will discuss the question of the democratic legitimacy of IRAs from a representative claims perspective.

To study IRAs from the perspective of the representative claim framework has brought into focus, first of all, for and on behalf of whom these independent agencies were established - who their supposed constituencies are, and which interests they are claimed to represent. In the "technocratic" approach, the legitimacy of IRAs is based on their "output": the "quality" of their policy results. The representative claims approach, however, puts front and centre who the (supposed) beneficiaries are of these results. Technocratic bodies do not operate in a vacuum; their claims to output legitimacy rest on implicit and explicit claims to represent constituencies. And so their activities can be evaluated differently. How well do IRAs serve economic and societal public interests? Are their constituencies satisfied with their performance? For technocratic bodies to consider themselves representatives of public interests, moreover, may contribute to a sense of mission as well as to greater public understanding of their role.

Secondly, this focus on the public interests claimed to be represented by IRAs creates new avenues for normative critique. In the "delegation" approach, IRAs are considered mere executive bodies, agents for their political principals; the traditional fabric of representative democracy is thought to remain intact. This view underestimates that lawmakers have set up bodies beyond direct electoral control with their own claims to constituency representation. This constitutes a historical transformation of the nature of representative democracy. Whereas before, elected parliaments represented the "general interest," now adjacent regulatory bodies also independently represent public and

115 Maggetti (2010) 2. 
consumer interests. IRAs, indeed, actively try to make people think of themselves as consumers. But the construction of these constituencies and the formulation of their interests is the product of a specific period: the age of the widespread liberalisation and marketisation of public domains from the $1980 \mathrm{~s}$ to the 2000s. Do people nowadays (still) want to be portrayed and represented as consumers? And if they do, do they feel sufficiently represented by IRAs? Viewing IRAs from the perspective of the representative claim framework makes it possible to ask such questions.

Thirdly, the representative claims approach to IRAs demonstrates the representational practices inherent to the interaction between these agencies and affected interests, such as corporations and interest groups. In "relational" approaches to the legitimacy of IRAs, this interaction is often conceptualised as "interactive policy-making," "horizontal accountability," or "participatory" or "deliberative" governance. Yet participation is often performed by representatives, who deliberate on behalf of interest and constituencies, while IRAs render account to these same representatives. When studying IRA-regulatee interaction, it is very worthwhile to consider which representational criteria regulate access to consultative procedures, who participates on behalf of whom, which representative claims lobbyists make, and how these are received by IRAs (and vice versa). Far from a technocratic affair, regulatory governance is about interests, and the representation of these interests is a political game that should be studied as such.

Lastly: this article has adopted and applied the viewpoint of Saward that representation should not be equated with institutional mechanisms like elections or with normative values like political equality. Representation is a discursive and performative process in which a claimant asserts an entity stands or acts for a constituency. Nevertheless, Saward holds that representative claims should be considered democratically legitimate when constituencies that a claimant intends to represent actually feel represented. Could this be applied to IRAs, which in traditional conceptions of representative democracy constitute an anomaly because they are not under full electoral control? Of course, finding out whether the various public and consumer constituencies that IRAs claim to represent, actually accept this claim, would require public opinion research. Still, IRAs can contribute to the public acceptance of their non-electoral representative claims. They could, for instance, always state clearly in whose interests their decisions are made. They could make their decision-making processes more transparent, and their outcomes easier to understand. And, considering the overrepresentation of corporate and professional interests in their consultative procedures, they could make an effort to more closely involve consumer and patient groups in consultations. 
This would enhance the credibility of IRAs' claim to represent public and consumer interests.

\section{List of Respondents}

IRA respondent 1: OPTA staffer.

IRA respondent 2: OPTA staffer.

IRA respondent 3: OPTA staffer.

IRA respondent 4: NMa Energy Chamber staffer.

IRA respondent 5: NMa Energy Chamber staffer.

IRA respondent 6: NMa Energy Chamber staffer.

IRA respondent 7: NMa Energy Chamber staffer.

IRA respondent 8: NMa Energy Chamber staffer.

IRA respondent 9: NMa Energy Chamber staffer.

IRA respondent 10: AFM staffer.

IRA respondent 11: AFM staffer.

IRA respondent 12: AFM staffer.

IRA respondent 13: AFM staffer.

IRA respondent 14: AFM staffer.

IRA respondent 15: NZa staffer.

IRA respondent 16: NZa staffer.

IRA respondent 17: NZa staffer.

IRA respondent 18: NZa staffer.

IRA respondent 19: NZa staffer.

IRA respondent 20: NZa staffer.

Stakeholder respondent 1: telecommunications corporation representative.

Stakeholder respondent 2: telecommunications corporation representative.

Stakeholder respondent 3: telecommunications corporation representative.

Stakeholder respondent 4: telecommunications corporation representative.

Stakeholder respondent 5: telecommunications corporation representative.

Stakeholder respondent 6: telecommunications corporation representative.

Stakeholder respondent 7: energy corporations representative.

Stakeholder respondent 8: energy corporations representative.

Stakeholder respondent 9: industrial energy consumers representative.

Stakeholder respondent 10: banking representative.

Stakeholder respondent 11: corporations listed at the stock exchange representative.

Stakeholder respondent 12: pension funds representative.

Stakeholder respondent 13: institutional investors representative.

Stakeholder respondent 14: stockowners representative. 
Stakeholder respondent 15: medical specialists representative.

Stakeholder respondent 16: medical specialists representative.

Stakeholder respondent 17: general practitioners representative.

Stakeholder respondent 18: dentists representative.

Stakeholder respondent 19: hospitals representative.

Stakeholder respodent 20: healthcare providers for people with disabilities representative.

Stakeholder respondent 21: residential and home care organisations representative.

Stakeholder respondent 22: healthcare insurers representative.

Stakeholder respondent 23: healthcare insurers representative.

Stakeholder respondent 24: healthcare insurers representative.

Stakeholder respondent 25: patients and healthcare consumers representative.

\section{Sources}

AFM, Jaarverslag 2003, AFM, 2004, [accessed online 16.04.2019: <https://www.afm.nl/ / profmedia/files/afm/jaarverslag/jv-2003.pdf > ].

AFM, Stichting Autoriteit Financiële Markten - Reglement ten behoeve van het Adviserend Panel van Vertegenwoordigende Organisaties, AFM, 2007, [accessed online 16.04.2019: <https://www.afm.nl/ /profmedia/files/afm/externe-samenwer king/huish-reglement-adviserend-panel-070415.pdf > ].

AFM, Jaarverslag 2008, AFM, 2009, [accessed online 16.04.2019: <https://www.afm.nl/ / profmedia/files/afm/jaarverslag/jv-2008.pdf > ].

AFM, Jaarverslag 2010, AFM, 2011, [accessed online 16.04.2019: <https://www.afm.nl/ / profmedia/files/afm/jaarverslag/jv-2010.pdf > ].

AFM, Jaarverslag 2012, AFM, 2013, [accessed online 16.04.2019: <https://www.afm.nl/ / profmedia/files/afm/jaarverslag/2012/jaarverslag-2012.pdf > ].

AFM, "Klantbelang centraal: Geef de klant wat hij nodig heeft," AFM, 2014, [accessed online 16.04.2019: <https://web.archive.org/web/20131115100214/http://www.afm.nl/ $\mathrm{nl} /$ over-afm/thema/klantbelang-centraal/producten-met-toegevoegde-waarde. aspx $>$ ].

AFM, "Adviserend panel van vertegenwoordigende organisaties," AFM, 2019, [accessed online 16.04.2019: <https://www.afm.nl/nl-nl/over-afm/organisatie/ext-stakehol ders $>$ ].

Consumer and Market Authority Establishment Act 2013. Wet van 28 februari 2013, houdende regels omtrent de instelling van de Autoriteit Consument en Markt (Instellingswet Autoriteit Consument en Markt), Staatsblad 102 (2013). 
Healthcare Market Structuring Act 2006. Wet van 7 juli 2006, houdende regels inzake marktordening, doelmatigheid en beheerste kostenontwikkeling op het gebied van de gezondheidszorg (Wet marktordening gezondheidszorg). Staatsblad $2006 \mathrm{nr} .415$.

Dan, S., S. Jilke, C. Pollitt, R. van Delft, S. van de Walle, and S. van Thiel, "Effects of Privatisation and Agencification on Citizens and Citizenship: An International Comparison," Eerste Kamer, 27 February 2012, [accessed online at 16.04.2019: < http:// www.eerstekamer.nl/id/vj45ispjadtf/document_extern/effects_of_privatisation_ and/f=/vj45itouzitp.pdf $>$ ].

Second Chamber, Regels inzake instelling van een college voor post- en telecommunicatiemarkt (Wet onafhankelijke post- en telecommunicatieautoriteit). Memorie van toelichting. 25128 nr. 3. Kamerstukken II (1996-1997a).

Second Chamber, Regels inzake de telecommunicatie (Telecommunicatiewet). Memorie van toelichting. 25533 nr. 3. Kamerstukken II (1996-1997b).

Second Chamber, Regels met betrekking tot de productie, het transport en de levering van elektriciteit (Elektriciteitswet 19...). Memorie van toelichting. $25621 \mathrm{nr} .3$. Kamerstukken II (1997-1998).

Second Chamber, Borging van publieke belangen. Brief van de minister-president, minister van Algemene Zaken. 27771 nr. 1. Kamerstukken II (2000-2001).

NMa, Jaarverslag 2008, NMa, 2009, [accessed online 16.04.2019: <https://www.acm.nl/ $\mathrm{nl} /$ publicaties/publicatie/5391/NMa-Jaarverslag-2008/> ].

NMa, “Organisatie," 2013a, [accessed online 16.04.2019: <http://web.archive.org/ web/ 20130311061424/http://www.nma.nl/over_de_nma/organisatie/default.aspx>].

NMa, "Missie, visie \& strategie," 2013b, [accessed online 16.04.2019: <http://web.ar chive.org/web/20130311055355/http://www.nma.nl/over_de_nma/missie_visie_ and_strategie/default.aspx $>$ ].

NMa, Jaarverslag 2012, NMa, 2013c, [accessed online 16.04.2019: <http://nmajaarver slag2012.acm.nl/jaarverslag/downloads/> ].

NZa, Jaarverslag 2007, NZa 2008, [accessed online 16.04.2019: <https://zoek.officiele bekendmakingen.nl/kst-25268-70-b4.pdf> ].

NZa, Jaarverslag 2009, $N Z a, 2010$, available at the author.

$\mathrm{NZa}$, "Regeling Adviescommissies NZa," NZa, 2010b, available at the author.

NZa, "Organisatie - Nederlandse Zorgautoriteit," NZa, 2014a, [accessed online 16.04. 2019: <https://web.archive.org/web/20140821141359/http://www.nza.nl/organisatie/ overdenza/> ].

NZa, "Missie - Nederlandse Zorgautoriteit," NZa, 2014b, [accessed online 16.04.2019: <https://web.archive.org/web/20140614154739/http://www.nza.nl/organisatie/ overdenza/98050>].

OPTA, Jaarverslag 2004, OPTA, 2005, [accessed online 16.04.2019: <https://www.acm.nl/ $\mathrm{nl} /$ publicaties/publicatie/8783/o PTA-Jaarverslag-2004-en-Visie-op-de-markt$2005>$ ]. 
OPTA, Jaarverslag 2005, OPTA, 2006, [accessed online 16.04.2019: <https://www.acm.nl/ nl/publicaties/publicatie/9039/opTA-Jaarverslag-en-Marktmonitor-2005/>].

OPTA, Jaarverslag 2010, OPTA, 2011 [accessed online 16.04.2019: <http://optajaarver slag2010.acm.nl/jaarverslag/downloads/>].

OPTA, “OPTA is een ZBO," OPTA, 2013a, [accessed online 16.04.2019: http://web.archive. org/web/20121003003805/http://www.opta.nl/nl/hoe-werkt-opta/opta-is-een$\mathrm{zbo} />$.

OPTA, "Morgen wordt vandaag bedacht," OPTA, 2013b, [accessed online 16.04.2019: <http://web.archive.org/web/20121003003543/http://www.opta.nl/nl/wat-doet-opta/morgen-wordt-vandaag-bedacht/> ].

OPTA, "Consuwijzer," OPTA, 2013c, [accessed online 16.04.2019: <http://web.archive. org/web/20120530065208/http://www.opta.nl/nl/wat-doet-opta/consuwijzer/> ].

Raad van State, Jaarverslag 1999, Raad van State, 2000, [accessed online 16.04.2019: <http://www.raadvanstate.nl/publicaties/jaarverslagen.html>].

Second Chamber, Hervorming van het toezicht op de financiële marktsector. Nota. 28 122 nr. 2. Kamerstukken II (2001-2002).

Second Chamber, Wijziging van de Telecommunicatiewet en enkele andere wetten in verband met de implementatie van een nieuw Europees geharmoniseerd regelgevingskader voor elektronische communicatienetwerken- en diensten en de nieuwe dienstenrichtlijn van de Commissie van de Europese Gemeenschappen. Memorie van toelichting. $28851 \mathrm{nr}$. 3. Kamerstukken II (2002-2003).

Second Chamber, Visie op markttoezicht. Bijlage bij 29 200-XIII nr. 50. Kamerstukken II (2003-2004a).

Second Chamber, Wijziging van de Elektriciteitswet 1998 en de Gaswet ter uitvoering van richtlijn nr. 2003/54/EG, (PbEG L 176), verordening nr. 2003/55/EG (PbEG L 176), alsmede in verband met de aanscherping van het toezicht op het netbeheer (Wijziging Elektriciteitswet 1998 en Gaswet in verband met implementatie en aanscherping toezicht netbeheer). Memorie van toelichting. $29372 \mathrm{nr}$. 3. Kamerstukken II (2003-2004b).

Second Chamber, Regels met betrekking tot de financiële markten en het toezicht daarop (Wet op het financieel toezicht). Memorie van toelichting. 29708 nr. 3 . Kamerstukken II (2003-2004c).

Second Chamber, Regels inzake marktordening, doelmatigheid en beheerste kos- tenontwikkeling op het gebied van de gezondheidszorg (Wet marktordening gezondheidszorg). Memorie van toelichting. 30186 nr. 3. Kamerstukken II (2004-2005).

Telecommunications Act Revision Act 2004. Wet van 22 april 2004 tot wijziging van de Telecommunicatiewet en enkele andere wetten in verband met de implementatie van een nieuw Europees geharmoniseerd regelgevingskader voor elektronische communicatienetwerken- en diensten en de nieuwe dienstenrichtlijn van de Commissie van de Europese Gemeenschappen. Staatsblad 189 (2004). 


\section{Literature}

Anderson, B.R.O'G., Imagined Communities. Reflections on the Origin and Spread of Nationalism (London, 1986).

Ankersmit, F., Aesthetic Politics. Political Philosophy beyond Fact and Value (Stanford, 1996).

Baldwin, R., M. Cave and M. Lodge, Understanding Regulation. Theory, Strategy and Practice (Oxford, 2012).

Berg, C. van den and M. Pars, “Wij willen zichtbaar zijn'. Over de legitimiteit en politieke profileringsdrang van de AFM," in Liberaal Reveil 53, no. 2 (2012), 84-89.

Black, J., "Constructing and Contesting Legitimacy and Accountability in Polycentric Regulatory Regimes," in Regulation \& Governance 2, no. 2 (2008), 137-164.

Bovens, M., "Two concepts of Accountability: Accountability as a Virtue and as a Mechanism," in West European Politics 33, no. 6 (2010), 946-967.

Coen, D. and M. Thatcher, "The New Governance of Markets and Non-Majoritarian Regulators," in Governance: An International Journal of Policy, Administration, and Institutions 18, no. 3 (2005), 329-346.

Duijkersloot, A.P.W., Toezicht op gereguleerde markten (Nijmegen, 2007).

Epstein, D. and S. O'Halloran, Delegating Powers: A Transaction Costs Politics Approach to Policy Making under Separate Powers (Cambridge, Eng., 1999).

Eulau, H. and P.D. Karps., "The Puzzle of Representation: Specifying Components of Responsiveness," in Legislative Studies Quarterly 2, no. 3 (1977), 233-254.

Gestel, R.A.J. van, P. Eijlander, and J.A.F. Peters, "The Regulatory Powers of Quangos in the Netherlands: Are Trojan Horses Invading our Democracy?," in Electronic Journal of Comparative Law 11, no. 1 (2007), 1-24, [accessed online 16.04.2019: <http://www. ejcl.org/111/art111-9.pdf> ].

Gilardi, F., Delegation in the Regulatory State. Independent Regulatory Agencies in Western Europe (Cheltenham, 2008).

Levi-Faur, D., "Regulatory Networks and Regulatory Agencification: Towards a Single European Regulatory Space," in Journal of European Public Policy 18, no. 6 (2011), 810-829.

Maggetti, M., "Legitimacy and Accountability of Independent Regulatory Agencies: A Critical Review," in Living Reviews in Democracy 2 (2010), 1-9.

Majone, G., "The regulatory state and its legitimacy problems," in West European Politics 22, no. 1 (1999), 1-24.

Majone, G., Regulating Europe (London, 1996).

Marochi, B., "Political Inclusion and Representative Claim-Making in Participatory Governance. Case Studies from Birmingham and Copenhagen," PhD Diss. (Roskilde Universitet, 2010). 
Papadopoulos, Y., "Accountability and Multilevel Governance: More Accountability, Less Democracy?," in West European Politics 33, no. 5 (2010), 1030-1049.

Pitkin, H.F., The Concept of Representation (Berkeley, 1967).

Pree, J. de, "Publieke belangen, overheidsbeleid en investeringen in infrastructuur," in G. Arts, W. Dicke, and L. Hancher (eds.), New Perspectives on Investment in Infrastructures (Amsterdam, 2008).

Sabel, C.F. and J. Zeitlin, "Learning from Difference: The New Architecture of Experimentalist Governance in the EU," in European Law Journal 14, no. 3 (2008), 271-327.

Saward, M., The Representative Claim (Oxford, 2010).

Saward, M., "Authorisation and authenticity: representation and the unelected," in Journal of Political Philosophy 17, no.1 (2009), 1-22.

Saward, M., "The representative claim," in Contemporary Political Theory 5, no. 3 (2006), 297-318.

Saward, M., "Governance and the Transformation of Political Representation," in J. Newman (ed.), Remaking Governance: Peoples, Politics and the Public Sphere (Bristol, 2005), 179-186.

Severs, E. “Representation as Claims-Making. Quid Responsiveness?," in Representation, 46, no. 4 (2010), 411-423.

Sosay, G., "Consequences of Legitimizing Independent Regulatory Agencies in Contemporary Democracies. Theoretical Scenarios," in D. Braun and F. Gilardi (eds.), Delegation in Contemporary Democracies (London, 2006), 172-190.

Stellinga, B., Dertig jaar privatisering, verzelfstandiging en marktwerking (Amsterdam, 2012).

Strom, K., W.C. Müller, and T. Bergman (eds.), Delegation and Accountability in Parliamentary Democracies (Oxford, 2003).

Teulings, C., L. Bovenberg and H.P. van Dalen, De calculus van het publieke belang (The Hague, 2003).

Thatcher, M. and A. Stone Sweet, "Theory and Practice of Delegation to NonMajoritarian Institutions," in West European Politics 25, no. 1 (2002), 1-22.

Thatcher, M., "The Third Force? Independent Regulatory Agencies and Elected Politicians in Europe," in Governance: An International Journal of Policy, Administration, and Institutions 18, no. 3 (2005), 347-373.

Thiel, S. van, Quangocratization: Trends, Causes and Consequences (ICs Dissertation Series, 2000).

Verhey, L.F.M. and N. Verheij, "De macht van de marktmeesters. Markttoezicht in constitutioneel perspectief," in Handelingen der Nederlandsche Juristen-Vereeniging ${ }_{135}$, no. 1 (2005), 135-332.

Vibert, F., The Rise of the Unelected. Democracy and the New Separation of Powers (Cambridge, Eng., 2007). 
Wetenschappelijke Raad voor het Regeringsbeleid, Het borgen van publiek belang (The Hague, 2000).

Wilde, P. de, "Representative Claims Analysis: Theory Meets Method," in Journal of European Public Policy 20, no. 2 (2013), 278-294.

Yackee, J.W. and S.W. Yackee, "A bias toward business? Assessing interest group influence on the U.S. bureaucracy," in Journal of Politics 68, no. 1 (2006) 128-139.

Zijlstra, S.E., Zelfstandige bestuursorganen in een democratische rechtsstaat (The Hague, 1997). 